\title{
DANSK KRONIK
}

\section{Folketingets ombudsmands beretning $195 \%$.}

Folketingets ombudsmand har i september 1958 afgivet sin tredie årsberetning (J. H. Schultz, København, 264 sider). Foruden omtale af embedets almindelige forhold, oversigt over de i 1957 behandlede sager $\mathrm{m}$. v. indeholder beretningen referat af 100 sager, herunder en del som har drejet sig om strafferetlige, processuelle eller politimæssige forhold, fx: værneting i politisager, fangers bes $\phi$ gstilladelse, tjenestemænds udtalelser om verserende straffesager, administrativ inddragelse af førerbevis, affattelse af rapporter, fjernelse af fotos fra politiets registre efter frifindende dom, prøvel $\varnothing$ sladelse fra sikkerhedsforvaring, anvendelse af håndjern overfor arrestanter og fremgangsmåden ved ransagning. Efter anmodning fra det af Folketinget $i$ henhold til grundlovens $\S 71$, stk. 7, nedsatte tilsyn (vedr $\varnothing$ rende administrativ frihedsber $\varnothing$ velse) har ombudsmanden unders $\phi$ gt spørgsmålet om n $\varnothing$ dvendigheden af samtykke til foretagelse af chokbehandling og operative indgreb (lobotomi) på patienter, der er indlagt på statens sindssygehospitaler; ligeledes spørgsmålet om beskikkelse af tilsynsværger for tvangsindlagte sindssyge patienter.

\section{Den særlige Klagerets virksomhed.}

I „Ugeskrift for Retsvæsen“ 1958 p. 196-206 gengives nogle af Den særlige Klagerets kendelser fra årene 1956 og 1957 vedrørende genoptagelse af straffesager. Det oplyses at der i to års perioden fra 1. juli 1955 til 30. juni 1957 indkom 197 begæringer om genoptagelse; 7 af disse blev taget til f $\varnothing$ lge, medens 177 blev af vist, forkastet eller henvist til andre myndigheder. 13 sager var uafsluttede pr. 30 . juni 1957.

\section{Arbejdshus.}

Om behandlingen af mandlige domfældte, der indsættes $\mathrm{i}$ arbejdshus, er der den 21. juli 1958 udfærdiget ny kgl. anordning til afløsning af den hidtil gældende anordning af 1946. Samtidig har justitsministeriet udfærdiget nyt reglement for de i arbejdshus indsatte domfældte.

\section{Betrenkning om kriminalstatistik.}

Justitsministeriet nedsatte $\mathrm{i}$ august 1955 et udvalg, som skulle overveje spørgsmålet om en eventuel nyordning af den danske kriminalstatistik. Til formand for udvalget udpegedes rigsadvokat $H$. Olafsson. Forud for udvalgets nedsættelse havde der været forskellige nordiske drøftelser om kriminalstatistiske spørgsmål, og et svensk udvalg havde i 1954 afgivet en omfattende betænkning (Statens offentliga utredningar 1954:35, omtalt af Hans Thornstedt i NTfK 1955 p. 166-70). De principielle synspunkter, som fandt udtryk i den svenske betænkning, er $\mathrm{i}$ det store og hele blevet tiltrådt af det danske udvalg, som 
nylig har afsluttet sit arbejde og afgivet en „Betænkning vedrørende en nyordning af kriminalstatistikken" (duplikeret, 140 sider +34 bilag). Betænkningens hovedafsnit handler om politistatistik (særlig antallet af anmeldte lovovertrædelser og af sigtede), domfældelses- og reaktionsstatistik, tiltalefrafald og tilbagefaldsstatistik. På alle punkter har man kritisk gennemgået den nugældende ordning og udformet detaillerede forslag om andringer med hensyn til tilvejebringelsen af primærmateriale og statistisk bearbejdelse.

\section{Kriminaliteten i København.}

If $\varnothing$ lge K $\phi$ benhavns opdagelsespolitis opg $\varnothing$ relser blev der i de f $\phi$ rste seks måneder af 1958 i K $\varnothing$ benhavn anmeldt 14.453 forbrydelser. Dette var 1.050 mindre end $i$ det første halvår af 1957.

Knud Waaben.

\section{NORSK KRONIKK}

Den 21. desember 1956 fikk professor, dr. jur. Johs. Andenæs i oppdrag av den svenske regjering å ,verkställa utredning om formerna för ökat nordiskt samarbete inom kriminologien". I september 1957 forelå en foreløpig utredning, som ble sendt de forskjellige kriminologiske institutter og andre sakkyndige i Norden til uttalelse.

Den endelige utredning forelå 28 . juni 1958 i stensilert stand (29 s.). Som sekretær har fungert universitetsstipendiat Nils Christie.

Innledningsvis pekes det $\mathrm{i}$ utredningen på den kriminologiske forsknings betydning for kriminalpolitikken. Deretter gjøres det rede for den kriminologiske forskning i Norden. Det nevnes at det etter krigen er blitt opprettet universitetsinstitutter for kriminologisk forskning i Århus, København, Oslo og Stockholm. I Finnland har man ved universitetet $\mathrm{i}$ Helsingfors et kriminalrettslig institutt som også omfatter kriminologien. Forel $\varnothing$ big mangler imidlertid instituttene fast vitenskapelig personale, når bortsees fra instituttet i København, hvortil er knyttet en dosent $\mathrm{i}$ kriminologi.

Spørsmålet er reist om ikke nordisk kriminologisk forskning på en eller annen måte bør samordnes. Således tok den svenske regjering i 1956 opp spørsmålet om det ikke skulle være behov for et nordisk forskningsinstitutt, drevet $\mathrm{i}$ fellesskap av forskere $\mathrm{i}$ de forskjellige land $\mathrm{i}$ Norden. Begrumnelsen var at man ved å slå sine ressurser sammen skulle kunne skape en mer effektiv forskningsinstitusjon enn de enkelte land kunne makte å få istand alene.

Utredningen kommer til, etter en avveining av de hensyn som taler for og imot opprettelsen av et nordisk forskningsinstitutt, at det er for tidlig å realisere en slik plan. En forutsetning for at det skal kunne arbeides effektivt $\mathbf{i}$ et nordisk institutt er at instituttene $\mathbf{i}$ de enkelte nordiske land er godt utbygget, slik at de kan skaffe til veie det nasjo- 
nale materiale som det nordiske institutt ville trenge. Forel $\phi$ pig er imidlertid ikke de nasjonale institutter godt nok utbygget til at de kan løse denne oppgave. Det synes derfor som det mest realistiske f $\phi$ rst å utbygge de nasjonale forskningsinstitutter og sørge for best mulig samarbeid mellom dem. Et nordisk institutt får i tilfelle komme senere som en overbygning over en slagkraftig kriminologisk forskning i de enkelte land.

Det anbefales derfor at man inntil videre tar sikte på en koordinering av nordisk kriminologisk forskning gjennom opprettelsen av et nordisk kriminologisk forskningsråd. Tanken om et slikt nordisk forskningsråd vant alminnelig tilslutning ved en konferanse mellom nordisk kriminologi-sakkyndige i Stockholm desember 1956.

Det drøftes så hvordan et nordisk forskningsråd b $\phi r$ organiseres. Det pekes på at det særlig er tre løsninger som er aktuelle: 1. Opprettelsen av et bevilgende nordisk forskningsråd som har til oppgave generelt å støtte den kriminologiske forskning i de nordiske land. Det antas at rådet, ifall denne løssning velges, $b \phi r$ ha til disposisjon ca. 400.000 svenske $\mathrm{kr}$. årlig til forskningsformål. 2. Rådets bevilgende funksjon begrenses til sammenlignende nordiske unders $\varnothing$ kelser. I så fall antas det tilstrekkelig at rådet får ca. 100.000 svenske kr. årlig til disposisjon til forskningsformål. 3. Rådet gis ikke noen bevilgende funksjon, men får sin virksomhet begrenset til å sørge for utveksling av informasjoner mellom de forskjellige nasjonale institutter, arrangere nordiske kriminologiske forskningsseminarer o. 1. - Uansett hvilket alternativ som velges (maksimumsalternativet, mellomløsningen eller minimumsalternativet) forutsettes det at forskningsrådet får et fast sekretariat med tilhold $i$ et av de nasjonale institutter. Det antas at sekretariatet $b \phi r$ ledes av en yngre velkvalifisert kriminolog i heltidsstilling og at han b $\phi \mathrm{r}$ l $\phi$ nnes som dosent eller preseptor. Forskningsrådet forutsettes å bestå av tre sakkyndige medlemmer fra hver enkelt land, representerende så vidt mulig de forskjellige kriminologiske hjelpevitenskaper (jus, psykiatri, sosiologi, psykologi etc.).

Fordeler og ulemper ved de forskjellige løssninger drøftes, og det konkluderes med at det forel $\emptyset$ pig synes mest realistisk å innstille seg på melloml $\varnothing$ sningen, som for $\varnothing$ vrig de fleste sakkyndige har uttalt seg for. Utgiftene anslås til ca. 150.000 svenske kr. årlig. (50.000 til sekretariatet, rådets møter og årlig kriminologisk forskningsseminar og kr. 100.000 til nordiske sammenlignende unders $\varnothing$ kelser.)

Det vil i høst på Gyldendals forlag komme ut en „hvitbok“ om Myklesaken redigert av h.r.advokat Annæus Schjødt jr. Boken, som blir meget omfangsrik, er etter det opplyste lagt an som ren dokumentasjon.

Justisdepartementet har i sommer foretatt en sterkt skjerpet trafikkkontroll, hvor delvis de nyeste trafikk-tekniske hjelpemidler, så som radarapparater $\mathrm{m}$. v. har vært tatt i bruk. Politiet mener at kontrollen har ført til en betydelig reduksjon i tallet på råkjørere. 
Tallet på elever ved arbeidsskolen har vært $\phi$ kende i de senere tid, og skolen har nå ca. 65 elever. 35 befinner seg $\mathrm{i}$ den åpne avdeling på Berg, 15 i den lukkede avdeling på Sem og 10 i den nylig opprettede lukkede avdeling i Oslo kretsfengsel. Noen få elever sitter i varetektsfengsel eller utholder straff $i$ forbindelse med forbrytelser begått under rømning.

Politistatistikken viser at det har vært en sterk stigning i kriminaliteten i 1957. Tallet på forbrytelser etterforsket av politiet viste en stigning fra 1956 til 1957 på 24 pst. Det knytter seg en viss usikkerhet til tallet, for så vidt som oppgaven for 1956 delvis er beregnet (det manglet oppgaver fra endel av landets politikamre), men det er iallfall på det rene at det har fumnet sted en markert stigning i kriminaliteten.

Oppgavene viser stigning for alle de viktigste forbrytelser, bortsett fra ran og utuktig handling med barn under 16 år. Stigningen var st $\varnothing$ rst for brukstyveri av motorcykler (fra 547 etterforskede saker til 1534, dvs. en $\emptyset$ kning på 180 pst.). Dermed er motorcykkeltyveriene blitt mer tallrike enn bilbrukstyveriene, som også viste en kraftig stigning (65 pst.).

Stigningen i kriminaliteten gjenspeiler seg også i reaksjonsstatistikken for 1957, selv om stigningen ikke har slått så kraftig ut her. Mens det i 1956 ble reagert med straff eller påtaleunnlatelse i forbrytelsessak mot 4552 personer var tallet i 19575035 , dvs. 11 pst. høyere.

Også i de foregående år har det vært stigning; i årene 1954-1957 viser reaksjonsstatistikken en $\varnothing$ kning på 30 pst. Denne ugunstige utvikling skyldes i første rekke at ungdomskriminaliteten er steget meget sterkt. Således er reaksjonshyppigheten pr. 1000 innbyggere i aldersgruppen $14-17$ år steget fra 3,72 i 1954 til 7,40 i 1957. De tilsvarende tall for aldersgruppen 18-20 år og 21-24 år er steget fra henholdsvis 4,34 til 5,07 og 3,29 til 4,46 i samme tidsrom. For personer over 25 år var reaksjonshyppigheten bare ubetydelig høyere i 1957 enn i 1954.

Reaksjonshyppigheten ved forbrytelser overfor de forskjellige :aldersgrupper i de senere år vil fremgå av den grafiske fremstilling utarbeidet av Statistisk Sentralbyrå.

Den sterke stigning i ungdomskriminaliteten faller særlig på vinningsforbrytelser, i f $\varnothing$ rste rekke tyverier og brukstyveri av motorvogn.

Når det gjelder for'seelsene viser reaksjonsstatistikken omtrent de samme tall i 1957 som i 1956. I alt ble i 195743.514 personer straffet for forseelse. Av disse ble 56 pst. straffet for overtredelse av løsgjengerlovens bestemmelser om alkoholmisbruk og 35 pst. for trafikkforseelser. Denne forseelsestype hadde for $\phi \mathrm{vrig} \phi \mathrm{kt}$ med 19 pst. siden 1956. Tallet på promillekjørere steg med 17 pst., fra 1571 straffede i 1956 til 1838 i 1957. 


\section{$\mathrm{Pr}$.}

Reaksjonshyppigheten for forbrytelser i ulike aldersgrupper.

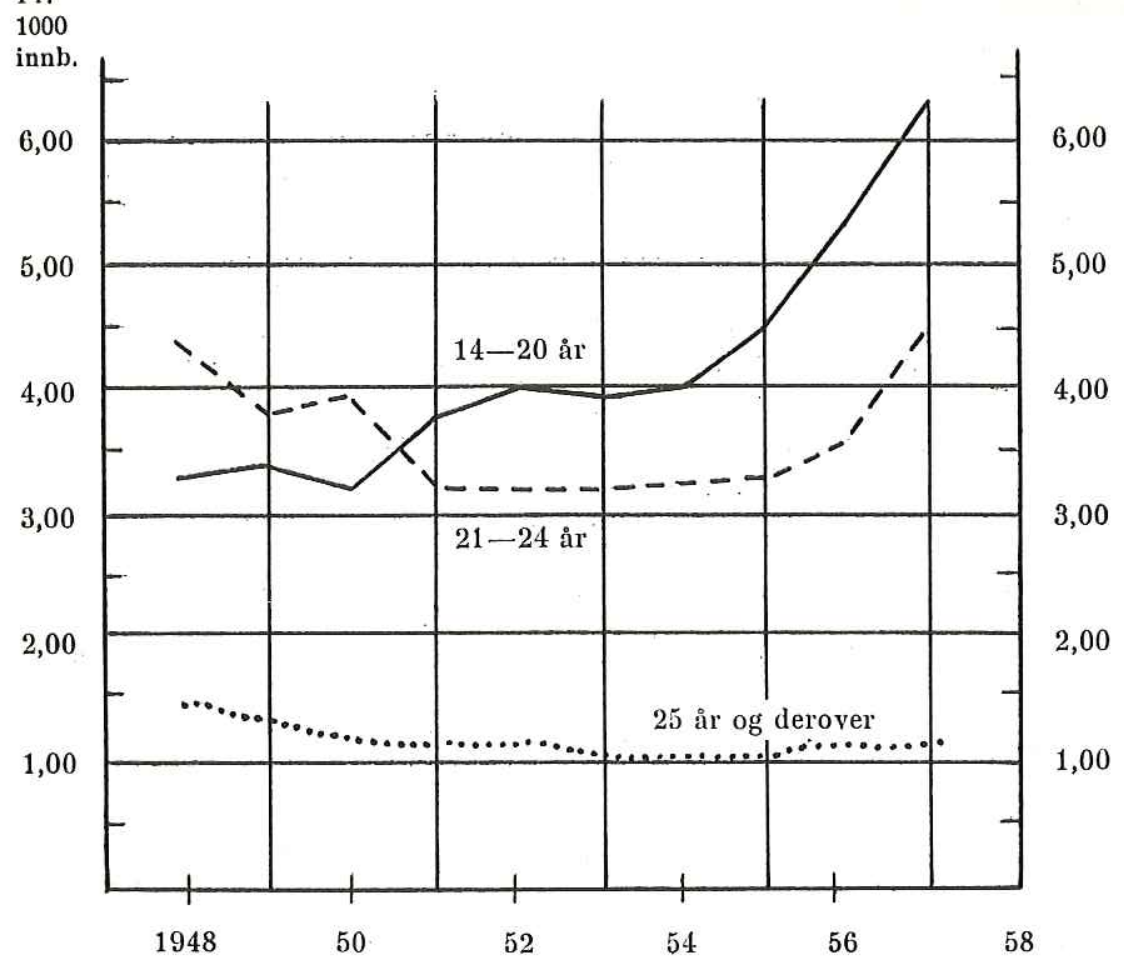

Den sterke stigning i ungdomskriminaliteten i den senere tid sammen med noen særlig alvorlige tilfelle av forbrytelser begått av ungdom, har ført til at pressen har beskjeftiget seg meget med kriminalitetsproblemene.

Diskusjonen har stort sett vært nøktern og saklig. De fleste synes å være enige om at man $b \varnothing r$ fors $\emptyset$ ke å bevare den nåværende kriminalpolitikk med liten anvendelse av ubetinget fengselsstraff overfor unge personer, men fra enkelte hold fremheves det at påtaleunnlatelse og betinget dom nå anvendes $\mathrm{i}$ en betenkelig vid utstrekning. Det blir fra mange hold fremholdt at det er nødvendig å styrke kriminalbehandlingen $\mathrm{i}$ frihet, slik at det kan settes inn mer effektive kontroll- og støttetiltak overfor dem som slipper med en betinget reaksjon.

Et hovedpunkt i diskusjonen har vært det sterkt $\phi$ kende antall brukstyverier av motorvogn, og flere aviser har rettet en henstilling til myndighetene om å påby rattlås på motorkjøretøyer.

Således skriver Verdens Gang, Oslo, redaksjonelt: „Mange vil nok mene at samfunnet selv er direkte medskyldig $\mathrm{i}$ at biltyverier er blitt en dagligdags ting som knapt noen reagerer på lenger, når det bare arter seg som „lån“ for noen timer. Biltyveriene er et typisk storby- 
fenomen. Det har selvsagt delvis sin bakgrumn i at så altfor mange av storbyens unge ikke har noe annet å ta seg til enn å slenge på et gatehjørne. Men ikke på noe annet område gjelder vel i så høy grad som her at leilighet gjør tyv. Det fins knapt den tolvåring i Oslo som ikke ville være i stand til å få startet en eller annen bil fra gatens parkeringsplass på mindre enn fem minutter. - Det er en grov fors $\phi$ mmelse når våre myndigheter ikke for lenge siden har sørget for å gjøre en så enkel ting som rattlås obligatorisk".

Det ble for $\emptyset$ vrig på kriminalistforeningens årsm $\phi$ te i november i år, hvor kriminalitetsutviklingen var forhandlingsemne, vedtatt at styret skulle sende en henvendelse til myndighetene om at eierne av motorkjøretøyer blir pålagt å benytte rattlås.

Om dette forslaget skriver Dagbladet, Oslo, redaksjonelt: „Justisdepartementet, som fikk oppfordringen fra våre fremste kriminalister i Norden, har nå utspillet. La Norge bli det første landet som vedtar en lov om sikring av bilene mot tyveri, en lov som er i and med de retningslinjene vi har fulgt ved behandlingen av unge lovovertredere. $\mathrm{Vi}$ må huske at her gjelder det bare sjelden ungdom som har noe forbrytersk i seg“.

Et utvalg nedsatt av sosialdepartementet har foresląt at det blir opprettet et alkoholforskningsinstitutt som en frittstående institusjon med en viss tilknytning til Norges almenvitenskaplige forskningsråd. Instituttet skal etter forslaget ha en egen forskningssjef og fire forskere i heldagsstilling. Edruelighetskomiteen av 1947 foreslo også at et slikt institutt skulle bli opprettet. - Utvalget har bestått av overlege Per Anchersen, direkt $\varnothing \mathrm{r}$ Erling Fjellbirkeland og departementsråd Agnar Kringlebotten (formann). Sekretær har vært universitetsstipendiat Nils Christie.

Ander's Bratholm. 